\title{
Curriculum as a Discourse: Using Critical Discourse Analysis to Revive Curriculum Reconceptualists' Thought
}

\author{
Majed Harb ${ }^{1, *}$ \\ ${ }^{1}$ College of Humanities and Social Sciences, Zayed University, Dubai, U.A.E \\ *Correspondence: College of Humanities and Social Sciences, Zayed University, Dubai, U.A.E E-mail: \\ Majed.Harb@za.ac.ae
}

Received: February 9, 2017

Accepted: March 1, 2017 Online Published: March 10, 2017

doi:10.5430/jct.v6n1p58

URL: https://doi.org/10.5430/jct.v6n1p58

\begin{abstract}
Curriculum reconceptualists seek to reshape the field of curriculum studies. Unlike traditional curricularists, they reprobate the technical approach of curriculum development because of its pure functional and managerial tendency. Reconceptualists look at curriculum from various philosophy-saturated perspectives. One of their claims is considering curriculum as a discourse, and the main task curricularists have to cope with is to understand this discourse.

Unfortunately, reconceptualists penetrate deeply into philosophy without offering a clear practical vision that helps them transform their insights. In this paper, I argue that reconceptualists can bridge the gap through considering Critical Discourse Analysis (CDA) assumptions. The idea of understanding curriculum as a discourse could be theoretically and practically detected when employing (CDA).
\end{abstract}

Keywords: curriculum as a discourse; reconceptualists; critical discourse analysis

\section{Introduction}

The idea of considering curriculum as a discourse implies investigating basic assumptions of both curriculum reconceptualists and critical discourse analysts. The former emphasized the idea of understanding curriculum (Pinar et al, 1995), the later emphasized that language is socially situated and could not be neutral (Fairclough. 1995)

In "Understanding Curriculum", Pinar et al (1995) stated that the crucial question in the field of curriculum study is how to understand curriculum not how to develop it. They insisted that curriculum could be clearly understood from various multiple perspectives, and that does not mean refuting technical models of curriculum development, but rather, not to take them for granted.

According to Pinar and his colleagues, curriculum is understood when considering it as a "text" or "discourse". They warned us that we have to surpass the exact linguistic meaning of the words "text" and "discourse" into their macro semantic meaning as they are practices and ideas that could be critically analyzed to elucidate their embodied meanings.

Among curriculum reconceptualists (also called critical theorists) is Ivor Goodson (1994). Goodson put one of the most explicit declarations that disclose the need to understanding curriculum when he talked about the alienation of curriculum theory: "there are not theories of curriculum but merely programs. They are utopian not realist, concerned only with what or might be, not with the art of possible" (p.26).

To give curriculum reconceptualists implications their due consideration, curriculum political and economic contexts (Apple, 1979) must not be overlooked. Giroux (1988) emphasized the importance of moving from micro technical level of understanding curriculum into macro sociopolitical level that closely interlinks the content taught with students' reality. The idea of Giroux was well explained by Maclaren (2003) who distinguished between productive and directive curricular knowledge.

According to Maclaren, curriculum enhances students' abilities to master uncontextualized information that is related to micro objectives and then asks them to "produce" knowledge. Directive knowledge, which is neglected, is built to meet macro objectives that interrogate political and economic contexts and enhance students to examine them 
critically.

Although reconceptualists emphasized the role of language in understanding curriculum, they did not suggest a particular procedure to examine how language shapes curriculum orientation, that's to say they were aware of the idea that curriculum is a political act aims at making an ideology accepted by others, but they did nothing to encounter the linguistic hegemony prevalent in curriculum.

This implies that curriculum reconceptualists need to employ Critical Discourse Analysis (CDA) assumptions as established in works of Van Dijk (1988a, 1988b), Wodak $(1995,2001)$ and Fairclough $(1993,1995,2003)$. In the following parts, I will discuss how reconceptualists see curriculum as a discourse and how we can better understand their insights from (CDA) perspective. The point here is that curriculum reconceptualists and critical discourse analysts share the same task of getting rid of the epistemological trap set by positivist.

To find out how (CDA) could be a great opportunity to revive reconceptualists' though and make it more applicable, I critically reviewed the literature of both reconceptualists and critical discourse analysts, and attempted to highlight their fundamental claims. This requires articulating the discursive nature of curriculum, and explaining how (CDA) could be a helpful tool for better understanding of this nature.

\section{The Discursive Nature of Curriculum}

Reconceptualists gave serious attention to Huebner's (1975) early attempt when he concluded that curriculum is trapped in a technical language built on experimentation and causality. Since then, reconceptualists were completely concerned with specific curricular issues missed by traditional curricularists.

Kliebard (1992) and Goodson (1998, 1994) were pioneers in understanding curriculum as a historical discourse. Their basic assumption is that present could not be understood unless we indeed understand the past. A classroom practice, for example, is understood when we percept its historical context: how had it been shaped? what conditions legitimized it over the days? The same is true with regard to curriculum documents and textbooks which are texts required awareness of historical conditions through which they emerged.

To make this historical understanding of curriculum consistent, we have to consider lives of teachers (Goodson, 1988), they are in the heart of curriculum, whose personal perspectives about curriculum and classroom practices are crucial for understanding curriculum historically, thus they are one of historical resources needed for understanding curriculum.

Van Manen (1982) and Willis (1991) used phenomenology to understand curriculum. Phenomenology refers to how an individual expresses a lived experience. Each individual has a personal consciousness about the situations he experiences in his life, and each experience refers to cognitive and psychological reactions to these situations.

Traditional curricularists discussed the meaning and ways of organizing learning experiences, but they ignored subjective meanings that a student may express when saying "I hate this topic". Searching such subjective meanings is at the heart of phenomenological understanding. When a teachers says " I feel teaching is boring", he expresses simply this experience, phenomenology is concerned with details and particulars behind this saying. Thus, knowledge resulted from phenomenological understanding is not facts or laws, but rather, it is structures of meanings (Magrini, 2013) reflect subjective understanding of a lived experience.

When an individual gives a lived experience a subjective meaning, he actually practices a hermeneutic act that may help us obtain deeper understanding of this experience (Boshoff, 2007). Each hermeneutic act is initiated with a preliminary reading of a phenomenon depending on individual's inner knowledge and system of belief, then one may compare his personal vision to what is said about the phenomenon, that's to say he compares between two perspectives subjective and objective.

Technical models of curriculum development assumed that teaching is technical practice, and teachers' competency is merely an instrumental act that represents the world of curriculum developers and managers, thus teacher is an "agent" who implements a predetermined plan that is not representing his world. In fact, these models do not consider teachers and students as individuals able to interpret experiences and give them subjective meanings.

Works of Grumet (1976) and Macdonald (1981) highlighted the importance of both student and teacher personal experiences from an existentialist perspective. They claimed that curriculum must assist student to achieve his freedom without which he is not existed. School culture may negatively affect students' freedom when it's taken for granted, it may be seen as obstacle prevents student to completely achieve freedom. Thus, teachers and students are invited to talk about themselves and their experiences to determine what barriers restrict them to be free. This 
biographical approach (Pinar, 1994) is an opportunity for both student and teacher to define themselves as "free individuals" who are able to create subjective meanings of what they are experiencing.

But this ability is threatened when students and teachers encounter two contradictory realities; inside and outside school (Akoury, 2011), and the result is more alienation and more anxiety. So, curriculum reconceptualists who understand curriculum as an existentialist discourse valued particular subjects such as literature, philosophy and arts as they empower students and teachers to involve in dialogues that free them from the clutches of alienation.

Some reconceptualists attempted to understand curriculum as aesthetical discourse. Eisner $(1985,1991)$ and Vallance (1975) claimed that curriculum is an artistic work that should provide students with aesthetical learning experiences to enhance their expressive language and imaginative capabilities. Eisner had developed the concept "connoisseurship" to refer to the art of perception and appreciation of curriculum qualities. Although connoisseurship requires aesthetical sensation, it reflects merely a personal impression that could not persuade the others. To understand curriculum aesthetically, we have to move from connoisseurship toward educational criticism, another concept developed by Eisner, by which he meant transforming our subjective appreciations into convincing public discourse. Educational critic is that who is able to describe qualities he had seen, interpret them contextually, render judges, and establish themes and meanings could be seen in other environments.

The point here is that curriculum, similar to any artistic work (e.g. sculpture, painting, music recital), could be understood aesthetically through detecting its uniqueness, wholeness, and harmony. Consequently, curricularists who believe in Eisner's insights are concerned with the idea of knowledge multiple representations (e.g. audio, visual, expressive) instead of reclining exclusively on one representation reflects technical knowledge. When curriculum is built on this multiplicity, students will have great opportunity to recall their imaginative capabilities.

On the other hand, feminist reconceptualists investigate the idea of curriculum masculinity. Their evidence-based works (see Pinar, 1997 and Sears, 1992) indicate the unbalanced ways through which male and female are treated in school. According to these reconceptualists, school policy, curriculum content, social practices, and classroom discourse enhance gender differences in favor of male culture. They call for gender-balanced curriculum in which learning experiences are selected and organized in accordance with these differences.

Additionally, the most serious works that investigated curriculum from a pure ideological perspective are those of Apple $(1979,1993)$. His thorough analysis of the concept of hegemony provides a sober understanding of how curriculum and political and economic structures are interlinked, hegemony "refers to an organized assemblage of meanings and practices, the central, effective and dominant system of meaning, values and actions we are lived" (Apple,1979,p.5).

Apple claimed that school is ideology-oriented institute that emphasizes some values and practices and neglects others. This hegemonic situation includes persuading others to accept status quo, thus curriculum is considered as a political tool that maintains the elites interests. Curriculum knowledge is not neutral, but rather, is selected to serve these interests, and this makes schooling an ideological act aims at reproducing social hierarchies.

It is believed that reconceptualists had been criticized because of their concentration on ideology, criticism and ethical issues. Doll (1993), who is a postmodernist recoceptualist, attempted to mollify this criticism when he suggested an alternative approach to Tyler's famous four questions. Although he brilliantly explained what he called "the four Rs" (Richness, Recursion, Relations and Rigor), Hok-chun (2002) argued that Doll's approach is ambiguous and not clear. Hlebowitsh (2004) put it clearly: "(reconceptualists) have to find a way to transcend their own proclivity toward criticism and protest, and frame a useful theory of conduct that could endure their own style of criticism" (p.269).

I argued that curriculum reconceptualists thought is valuable and deserves more and more investigations, nevertheless, I agree completely with abovementioned critical claims. Reconceptualists need to cast off the burden of distancing theory from practice. In the following part, I will discuss how critical discourse analysis may help in bridging this gap. My standpoint is that whether we are talking about curriculum as a text, social practices in classrooms or lived experiences, we are talking about a discourse.

\section{Critical Discourse Analysis (CDA): Sniping the Opportunity}

The origin of Critical Discourse Analysis (CDA) is the field of critical linguistics which assumes that language is a social act, and social structures and linguistic structures are interlinked. One of (CDA) leading researchers is Van Dijk (1988a, 1988b, 2006), whose insights contribute remarkably to this field of study. Van Dijk began his work by analyzing both media texts that represent ethnical groups (Van Dijk, 1988a) and news texts (1988b). 
In his socio-cognitive approach, Van Dijk articulated two levels of language use; micro which refers to grammars, semantics, rhetoric... and macro which refers to the social context in which language is used. He called the former "hard structure" of language, and the later "soft structure". Text is an ideological product of an institute (media, press, school...), and to understand it we have to surpass its hard structure into soft one to warrant understanding its political and economic institutional assumptions. Thus, discourse analysis is concerned with embodied power relations that can be discovered only when we take into account these assumptions; the idea here is that discourse analysis is a pure ideological act.

In a later work, Van Dijk (2006) claimed that both language and ideology are collective acts and socially shared. Ideology, whether it is negative (e.g. racism) or positive (e.g. antiracism), often permeates into people through language. When people accept a particular ideology, this ideology uses language to keep this acceptance maintained, it represents itself positively through specific linguistic expressions and, at the same time, distains others by different passive expressions.

This idea was clearly explained by Wodak $(1995,2001)$ who investigated how language establishes social practices related to ethnicity and sexism. According to Wodak, any discourse is ideology-driven, it addresses those how were indoctrinated by ideology values and norms. Each discourse has its own historical nature (Wodak, 2001) that could be interpreted through checking its relations to other discourses. Wodak believed that there is no one right interpretation; she invited us to extend our interpretations toward hermeneutically understanding of discourse.

One of (CDA) most prominent pioneers is Fairclough who early called this field "critical language study". Fairclough $(1993,1995,2003)$ assumed that some social relations take through language an exploitive character. He articulated three levels of (CDA): descriptive, interpretative and explanative. In the first level we look at a discourse as it is a cohesive linguistic system consists of syntax, morphology and semantics. The second level is discourse practice, in which we consider discourse as a product and those who receive it as consumers, thus practicing a discourse refers to the process of production and consumption of a text. In this level, similar to Wodak's vision, consumers interpret discourse in light of its relations to other discourses, the idea which refers to intertextuality. Similar to Van Dijk's soft structure, the explanative level is concerned with discourse sociocultural contexts to determine how a discourse reshapes power in society to ensure dominant ideology penetration.

What is understood by the claims of critical discourse analysts is that language is not an arbitrary entity but, rather, intended one, it is a social practice through which reality is represented, and hegemony, power and prejudice are constituted.

In fact, there is no particular methodology to conduct (CDA), any methodology that may result in clarifying social meanings or hegemonic features included in a discourse could be useful, that is because of that the purpose of (CDA) is not to study language, but rather to highlight these meanings and features (Lee, 2011, Nor \& Aziz, 2010). Thus, (CDA) requires an enlightened eye able to ideologically deconstruct gender, race and sexism stereotyped roles in society (Pimental, 2010) as these roles represent biased discourses.

Many educational researchers (see Avendano \& Fonseca, 2009; Cohen, 2012; Herbel- Eisenmann \& Wanger, 2012; Sadeghi et al, 2012) believed in (CDA) as a theory and a research method. Their standpoint is that educational environments are purely discursive and teem with complex variables.

The well-done work that encourages us to consider (CDA) in the field of education is that of Rogers (2004). Rogers sought to "conceptualize the relationship between language form and function in educational settings and merge (CDA) with theories of learning... (and) demonstrates the ways in which (CDA) is put to work critical ethnographic and interpretive research in education" (p.ix). According to Rogers, discourse is a set of meanings that reflects ideas and values of a system; it is concerned with language purpose and function, in other words, in language in use. She claimed that intentionality is essential when analyzing a discourse and the aim of (CDA) is not to analyze just what had been said or practiced, but also to analyze what is untold or hidden.

The use of (CDA) in educational settings means that learning is regarded as social practices change over time and place, and this "can help educators describe, interpret, and explain the ways of interacting, representing, and being that accompanies learning" (Rogers, 2004. p.248). Herbel-Eisenmann \& Wanger (2012) investigated classroom discourse in math classes. Using (CDA), they argued that teachers use language to express their power inside classroom, they employ sharp lexical bundles indicate high discursive authority. Their declarative language makes them oppressive owners of information they provide.

Similarly, Sadeghi et al (2012) used (CDA) to investigate hidden social meanings behind classroom discourse in one of Iranian universities. Their study revealed that classroom discourse was masculine, female students used to endorse 
their male colleagues' discourse which is firm, imperative and data-oriented. Actually, this inside-classroom practices mirror power relations in society.

Using assumptions of (CDA), Lee (2011) analyzed English textbooks taught for high school students in S. Korea. Texts included in these textbooks, Lee argued, disdains Asian and African cultures and glorifies that of the United States which, according to the textbooks, respects gender differences and enhances quality education. S. Korea embraces economically neo-liberalism, so English is used not as merely a second language, but also as a tool to reinforce a dominant ideology.

I argue that (CDA) can contribute to curriculum reconceptualists thought in two ways. First, it helps make their assumptions less abstract and more realistic. Reconceptualists' philosophy-saturated insights minimize to some extend the social utility of their efforts, considering (CDA) in analyzing curriculum documents or classroom life leads to trace language levels described by Van Dijk and Fairclough to contextualize what is practiced in school. Historical, phenomenological, hermeneutical, aesthetical or feminist understanding of curriculum could evidently be in hand through (CDA).

Secondly, reconceptualists' thought deserves research methodology that chime in with their critical spirit. It is obvious that recoceptualists refuse quantitative methodologies as they represent isolationist thought (Watson \& Watson, 2011), and prefer qualitative ones. But, we have to note that both quantitative and qualitative are indeed similar in that both of them had paid no attention to political and sociocultural contexts, they ignore the fact that reality is shaped through social, economic, and political values (Scotland, 2012), they overlook the idea that language does not name things arbitrary, it could be used for either empowerment or marginalization. These ontological assumptions are in the heart of (CDA), and represent a good opportunity curriculum reconceptualists have to snipe if they want to reduce criticism severity they face.

\section{Conclusion and Implications}

A long time ago, I was very impressive by curriculum reconceptualists, I believe in most of their arguments. The traditional technical manipulation of curriculum is useful for curriculum developers and managers not for students. I completely agree with reconceptualists in rejecting causal relations as they do not interpret much of human behavior. Decontextualizing learning and teaching, the idea criticized strongly by reconeptualists, is the most dangerous dilemma that threatens educational settings.

I will, here, borrow Eisner's (1991) expression "instrumental utility" which refers to those research efforts that can help us understand an elusive situation and enhance our ability to predict and look ahead. In spite of their sober intellectual works and of their banner "how to understand curriculum", reconceptualists lack to visions that make their various approaches of high instrumental utility.

As they regarded curriculum as a discourse, reconceptualists can gap this rift by integrating their insights with those of (CDA). Curriculum as expressed in written documents, verbal interactions inside classroom, or social practices, could be critically analyzed. This critical analysis is what makes curriculum really understood.

It is crucial to say that connecting reconceptualists' thought to claims of critical discourse analysis requires contextualizing teaching. Kincheloe, Slattery, \& Steinberg (2000) argue that the idea of textualizing teaching means "rejecting of grand narratives or universal explanations of history" (p.10), and raising the "important of intuition, imagination, emotion, arts and spiritulaity" (p.10). Moreover, it is the responsibility of teachers to consider racial, gender, and physical identities of students.

I believe that language education could be the intersection point that link reconceptualists to critical discourse analyists. Many of critical issues raised by recoceptualists may be discussed through language teaching and learning. Fairclough (1989) suggested a three-part cycle that can be helpful when highlighting these issues. He talked about " reflection on experience" where students are asked to reflect upon their own experiences through langugae skills, "systemizing experience" which refers to how teacher helps students to express these reflections in a systematic form, and " explanation" where students' expressions lead to " further collective reflections and analysis by the class, and social explanations are sought" (p.242).

Another way to think about is to consider what Henderson and Kesson (2004) call "curriculum wisdom", which means "the attempt to transform courses of study into instances of democratic living" (p.92), that is to say understanding curriculum as a discourse requires reshaping the relationship between subject matter, democratic self, and social learning. 
The two perspectives, those of Fairclough and Henderson and Kesson, may provide insights that help in decreasing the burden of theorizing that characterizes reconceptualists' thought, and at the same time, in showing how (CDA) claims could be helpful in enhancing individuals' crirical consciuosness while using languuge. I argue that moving towards such a tendency will keep doors opend for those who are interested in investigating novel issues in curriculum futuristic theory

\section{References}

Akoury, P. (2011). An existential perspective on curricular relevance. Journal of Thought, Spring-Summer, 97-108. https://doi.org/10.2307/jthought.46.1-2.97

Apple, M. (1979). Ideology and Curriculum. 1st edition. London: Routledge \& Kegan Paul. https://doi.org/10.4324/9780203241219

Apple, M. (1993). Official knowledge: Democratic education in a conservative age. New York: Routledge.

Avendano, C., \& Fonseca, M. (2009). Use of discourse analysis to enhance students' critical thinking skills. Zona Proxima, 10, 36-49.

Boshoff, A. (2007). A Hermeneutical approach to curriculum interpretation: Deconstruction as a learning activity. Unpublished Master Dissertation, University of South Africa.

Cohen, J. (2010). Teachers in the news: A critical analysis of one US newspaper's discourse on education, 2006-2007. Discourse: Studies in the Cultural Politics of Education. 31(1), 105-119. https://doi.org/10.1080/01596300903465450

Eisner, E. (1985). The educational imagination (2nd ed.). New York: Macmillan.

Eisner. E. (1991). The enlightened eye (1st ed.). New York: Macmillan.

Fairclough, N. (1989). Language and power. New York: Longman.

Fairclough, N. (1993). Critical discourse analysis and the marketisation of public discourse. Discourse and Society, 4, 133-168. https://doi.org/10.1177/0957926593004002002

Fairclough, N. (1995). Critical discourse analysis: The critical study of language. New York: Longman.

Fairclough, N. (2003). Analysing discourse: Textual analysis for social research. New York: Routledge.

Giroux, H. (1988). Teachers as intellectuals. Westport, CN: Bergin \& Garvey.

Goodson, H. (1988). The making of curriculum (2nd ed.). Washington, DC: The Falmer Press.

Goodson, I. (1994). Studying curriculum: Cases and methods (1st ed.). Teacher College Press, Columbia University.

Grumet, M. (1976). Existential and phenomenological foundations. In W. Pinar, \& M. Grumet, Toward a poor curriculum. Dubuque, LA:Kendall/Hunt.

Henderson, J., \& Kesson, K. (2004). Curriculum wisdom. New Jersey: Upper Sadler River.

Herbel-Eisenmann, B., \& Wanger, D. (2010). Appraising lexical bundles in mathematics classroom discourse: Obligating and choice. Educational Studies in Mathematics, 75(1), 43-63. https://doi.org/10.1007/s10649-010-9240-y

Hlebowitsh, P. (2004). The burdens of the new curriculaists. In D. Flinders \& S. Thornton (eds.), The curriculum studies reader $\left(2^{\text {nd }}\right.$ ed.). Rout ledge Flamer.

Hok-chun, D. (2002). Quality education through a post-modern curriculum. Hong Kong Teacher's Centre Journal, 1, 56-73.

Huebner, D. (1975). Curricular language and classroom meanings. In W. Pinar (ed.), Curriculum theorizing: The reconceptualists. Berkeley, CA: McCutchan.

Kincheloe, J., Slattery, P., \& Steinberg, S. (2000). Contextualizing Teaching. New York: Longman.

Kliebard, H. (1992). Forging the American curriculum: Essays on curriculum history and theory. London: Routledge.

Lee, I. (2011). Teaching how to discriminate: Globalization, prejudice, and textbooks. Teacher Education Quarterly, Winter, 47-63. 
Macdonald, J. (1981). Curriculum, consciousness, and social change. Journal of Curriculum Theorizing, 3(1), 143-153.

Magrini, J. (2013). Phenomenology as curriculum inquiry: Understanding the methods of George Willis and Max van Manen. Paper presented at College of DuPage conference, Glen Ellyn, IL.

Mclaren, P. (2003). Life in schools: An introduction to critical pedagogy in the foundation of education. New York: Peter Lang.

Nor, N., \& Aziz, J. (2010). Discourse analysis of decision making episodes in meetings: Politeness theory and critical discourse analysis. The Southeast Asian Journal of English Language Studies, 16(2), 66-92.

Pimental, C. (2010). Critical race talking in teacher education through movie analysis. Multicultural Education, Spring, 51-56.

Pinar, W. (1994). Autobiography, politics, and sexuality: Essays in curriculum theory 1972-1992. New York: Peter Lang.

Pinar, W. (1997). Regimes of reason and male narratives voice. In W. Gierney \& Y. Lincoln (eds.). Representation and the text. Albany: State University of New York Press.

Pinar, W., Renolds, W., Slattery, P., \& Taubman, P. (1995). Understanding curriculum. New York: Lang.

Rogers, R. (editor) (2004). An introduction to critical discourse analysis in education (1st ed.). NJ: Lawrence Erlbaum.

Sadeghi, S., Ketabi, S., Tavakoli, M., \& Sadeghi, M. (2012). Application of critical classroom discourse analysis (CCDA) in analyzing classroom interaction. English Language Teaching, 5(1), 166-173.

Sear, J. (1992). Sexuality and the curriculum. New York: Teacher College Press.

Vallance, E. (1975). Aesthetic criticism and curriculum description. Unpublished doctoral dissertation. Stanford University.

Van Dijk, T. (1988a). News analysis: Case studies of international and national news in press. Hillsdale, NJ: Lawrence Erlbaum.

Van Dijk, T. (1988b). News as discourse. Hillsdale, NJ: Erlbaum.

Van Dijk, T. (2006). Ideology and discourse analysis. Journal of Political, 115-140. https://doi.org/10.1080/13569310600687908

Van Manen, M. (1982). Phenomenological pedagogy. Curriculum Inquiry, 12(3), 283-299. https://doi.org/10.1080/03626784.1982.11075844

Watson, S., \& Watson, W. (2011). Critical, emancipatory, and pluralistic research for education: A review of critical systems theory. Journal of Thought, fall, 63-77. https://doi.org/10.2307/jthought.46.3-4.63

Willis, G. (1991). Phenomenological inquiry: Life-world perceptions. In E. Short (ed.), Forms of curriculum inquiry. State University of New York Press.

Wodak, R. (1995). Critical linguistics and critical discourse analysis. In J.Verschueren, J. Ostman, \& J. Blommaert (eds.), Handbook of pragmatics. Amsterdam: John Benjamins Publishing. https://doi.org/10.1075/hop.m.cri1

Wodak, R. (2001). The discourse-historical approach. In R. Wodak \& M. Meyer (eds.), Methods of critical discourse analysis. London: SAGE. https://doi.org/10.4135/9780857028020.n4 